International Journal of Advanced Academic Research (Sciences, Technology and Engineering) | ISSN: 2488-9849

Journal DOI: 10.46654/ij.24889849

Vol. 7, Issue 1 (January, 2021)|www.ijaar.org

Article DOI: 10.46654/ij.24889849.e7114

\title{
AIR POLLUTION; CAUSES, EFFECTS AND REMEDIATION IN NIGERIA
}

\author{
Fagorite, Victor Inumidun ${ }^{1}$; Anifowose, Feyisayo Aderemi ${ }^{2}$ and Chiokwe, Victor Nnamdi ${ }^{3}$ \\ ${ }^{1}$ Department of Geology, Federal University of Technology, P.M.B 1526, Owerri, Nigeria \\ ${ }^{2}$ Department of Environmental Science, University of Louisiana at Lafayette, PO Box 43716,
} LA, USA

${ }^{3}$ Krisoral Group of Companies, Onitsha, Nigeria

Email:fagorite@gmail.com

\begin{abstract}
More recently, air pollution has been a prevailing issue for discussion due to its adverse health and environmental effects in major cities and more importantly the Niger Delta region as a whole. Air pollution is the introduction of chemicals, particulate matter, or biological materials that cause harm or discomfort to humans or other living organisms, or cause damage to the natural environment or built environment, into the atmosphere. The causes of air pollution are either natural or anthropogenic. While its effects could be health or environmental. In terms of remediation, there are now practical alternatives to the principal causes of air pollution. For instance, combustion of fossil fuels for space heating can be replaced by using ground source heat pumps and seasonal thermal energy storage. Commonly used as pollution control devices by industry or transportation devices which can either destroy contaminants or remove them from an exhaust stream before it is emitted into the atmosphere has been listed. Also, motor vehicles driven by fossil fuels, a key factor in urban air pollution can be replaced by electric vehicles. This has led us to present a general overview of the causes, effects and remediation of air pollution with a little focus on Nigeria. Finally, when it comes to the Niger Delta, there are numerous challenges facing air quality studies such as; lack of equipment, lack of infrastructure, inadequate expertise and weak policy framework.
\end{abstract}

Keywords: Air Pollution, Niger Delta, Acid Rain, Climate Change and Air Quality. 


\section{INTRODUCTION}

As we proceed more into the industrial age of technology and urbanization, it is clearly understood that it has changed several aspects of human life. The populace benefits largely from the developments that emanate from these and many live in prosperity, but prosperity has a price. This price is paid by our environment that suffers daily from all kinds of pollutants, including destruction of the atmospheric environment. This increases the overall toxic burden of the environment (Njoku \& Ibe, 2009). Pollution is defined by the European Union 1996 Council Directive on Integrated Pollution Prevention and Control (IPPC, 1996) in Fagbeja et al. (2008) as "the direct or indirect introduction as a result of human activity, of substances, vibrations, heat or noise into the air, water or land which may be harmful to human health or the quality of the environment, result in damage to material property, or impair or interfere with amenities and other legitimate uses of the environment."

Air pollution is the introduction of chemicals, particulate matter, or biological materials that cause harm or discomfort to humans or other living organisms, or cause damage to the natural environment or built environment, into the atmosphere (Tawari \& Abowei, 2012). It can be defined as the presence in the outdoor or indoor atmosphere of one or more gaseous or particulate contaminants in quantities, characteristics and of duration such as to be injurious to human, plant or animal life or to property, or which unreasonably interferes with the comfortable enjoyment of life and property (Odigure, 1998).

Air pollution is one of the problems associated with the growing population of various cities. This has increased tremendously with urbanization and associated industrial development and growth in mobility which have deteriorated air quality and intensified air pollution in densely populated areas. The severity of the air pollution problems in the cities reflects the level and speed of development (APMA, 2002; Molina et al., 2004; Grutter et al., 2014), and most of these pollutants are emitted from "fugitive" sources such as evaporation of solvents or leaks at industrial facilities, incinerators and flare stacks can also be source of atmospheric emissions (Fort Air Partnership (FAP), 2014). The main objective of the study is to present a general overview of the causes, effects and remediation of air pollution with a little focus on Nigeria.

\section{CAUSES OF AIR POLLUTION}

The causes of air pollution can be divided into two; natural and anthropogenic causes.

\section{Natural Causes}

The natural forms of pollution are those that result from naturally-occurring phenomena. This means they are caused by periodic activities that are not man-made or the result of human activity. What is more, these sources of pollution are subject to natural cycles, being more common under certain conditions and less common under others. Being part of Earth's natural climatic variations also means that they are sustainable over long periods of time. The following are some examples; 


\section{Dust and wild fire}

In large areas of open land that have little to no vegetation, and are particularly dry due to a lack of precipitation, wind can naturally create dust storms (Figure 1). This particulate matter, when added to the air, can have a natural warming effect and can also be a health hazard for living creatures. Particulate matter, when scattered into regions that have natural vegetation, can also be a natural impediment to photosynthesis.

Wildfires are a natural occurrence in wooded areas when prolonged dry periods occur, generally as a result of season changes and a lack of precipitation. The smoke and carbon monoxide caused by these fires contribute to carbon levels in the atmosphere, which allows for greater warming by causing a Greenhouse Effect.

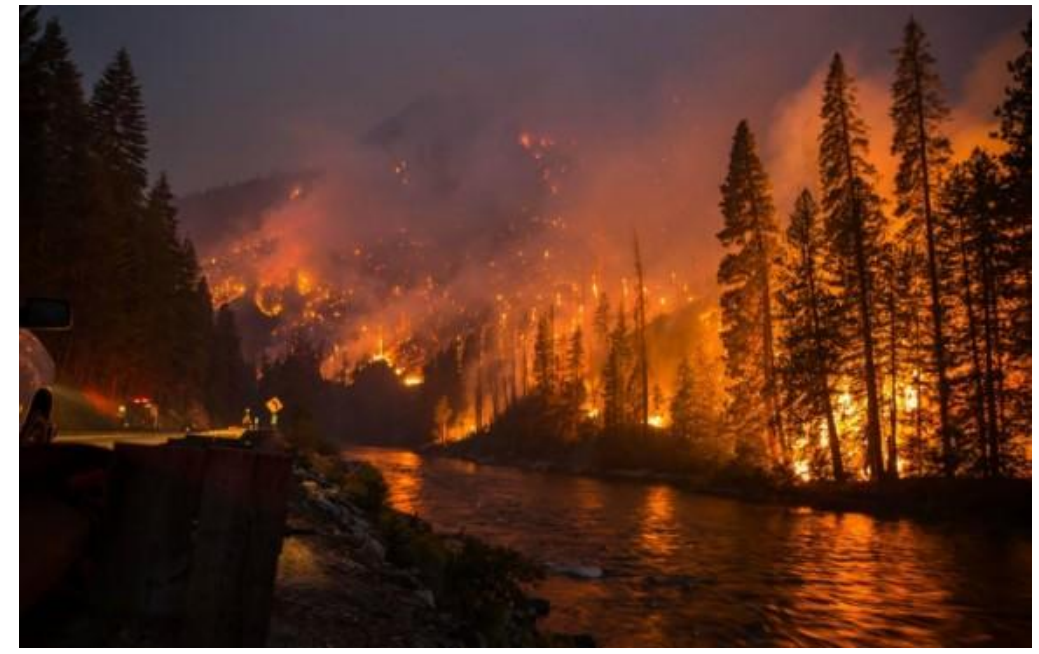

\section{Figure 1: The Chiwaukum Fire in Washington State in 2014 (Source: Washington DNR/flickr).}

\section{Animal and Vegetation}

Animal digestion (particularly by cattle) is another cause of natural air pollution, leading to the release of methane, another greenhouse gas. In some regions of the world, vegetation - such as black gum, poplar, oak, and willow trees - emits significant amounts of volatile organic compounds (VOCs) on warmer days. These react with primary anthropogenic pollutants specifically nitrogen oxides, sulfur dioxide and carbon compounds - to produce low-lying seasonal hazes that are rich in ozone.

\section{Volcanic Activity}

Volcanic eruptions are a major source of natural air pollution. When an eruption occurs, it produces tremendous amounts of sulfuric, chlorine, and ash products, which are released into the atmosphere and can be picked up by winds to be dispersed over large areas. Additionally, 
compounds like sulfur dioxide and volcanic ash have been known to have a natural cooling effect, due to their ability to reflect solar radiation.

\section{Anthropogenic Causes}

This is by far the greatest contributing to air pollution today as a result of human impact - i.e. man-made causes. They are largely the result of human reliance on fossil fuels and heavy industry, but can also be due to the accumulation of waste, modern agriculture, and other manmade processes. Some examples are discussed.

\section{Fossil-Fuels Emissions}

The combustion of fossil fuels like coal, petroleum from vehicles and other factory combustibles is a major cause of air pollution (Figure 2). These are generally used in power plants, manufacturing facilities (factories) and waste incinerators, as well as furnaces and other types of fuel-burning heating devices. Providing air conditioning and other services also requires significant amounts of electricity, which in turn leads to more emissions.

According to the Union of Concerned Scientists, industry accounts for $21 \%$ of greenhouse gas emissions in the US, while electricity generation accounted for another $31 \%$. Meanwhile, emissions caused by gasoline-burning vehicles - i.e. $\mathrm{CO}, \mathrm{CO}_{2}$, nitrogen oxides, particulates and water vapor - are also a significant source of air pollution.

A study conducted by the UCS in 2013 showed that transportation accounted for more than half of the carbon monoxide and nitrogen oxides, and almost a quarter of the hydrocarbons emitted into the air in the US. Globally, the situation is similar, with minor variations according to sector. According to the 2014 IPCC Fifth Assessment Report, industry accounted for $21 \%$ of total greenhouse gas emissions, electricity and heat production for another $25 \%$, and transportation accounted for $14 \%$.

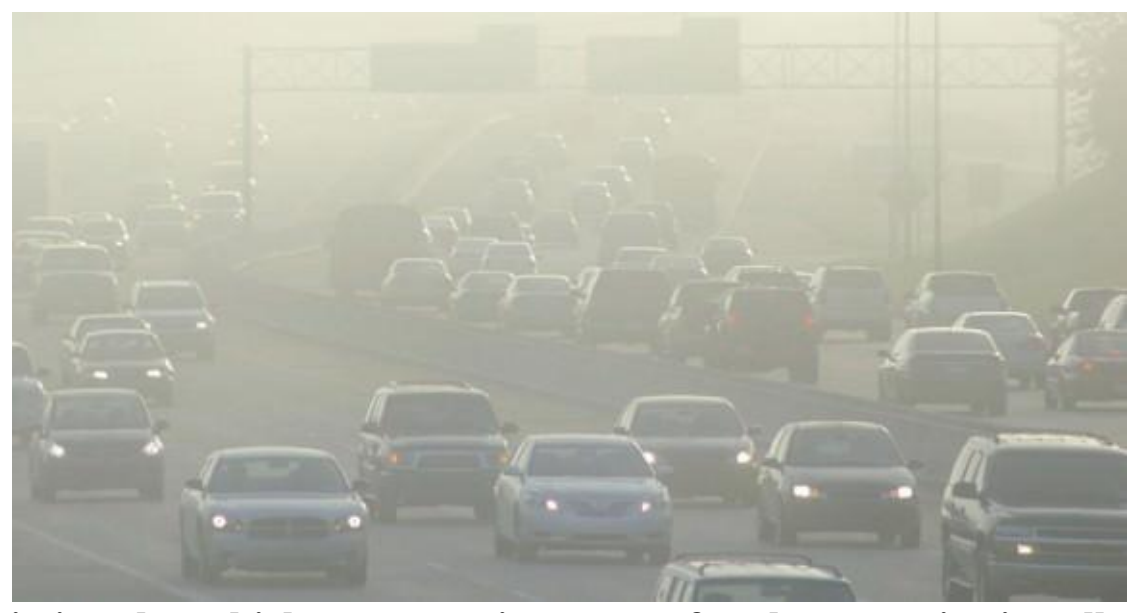

Figure 2: Emissions by vehicles are a major cause of anthropogenic air pollution (Source: ucsusa.org). 


\section{Agriculture and Animal Husbandry}

Greenhouse gas emissions from agriculture (the cultivation of crops and livestock) is created by a combination of factors, one is the production of methane by cattle (Figure 3). Another cause is deforestation, where the need for pastureland and growing fields requires the removal of trees that would otherwise sequester carbon and clean the air.

According to the IPCC Fifth Assessment Report, agriculture accounts for 24\% of annual emissions. However, this estimate does not include the $\mathrm{CO}_{2}$ that ecosystems remove from the atmosphere by sequestering carbon in biomass, dead organic matter and soils, which offset approximately $20 \%$ of emissions from this sector.

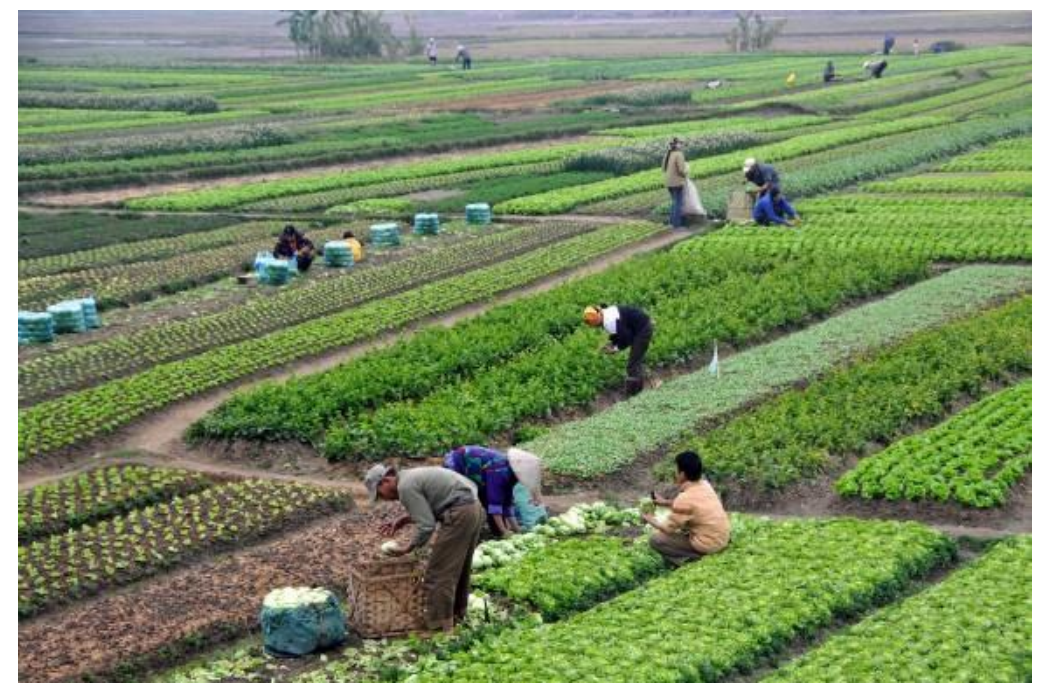

Figure 3: Agricultural activity accounts for $24 \%$ of annual greenhouse gas emissions globally (Source: Dennis Jarvis/Flickr).

\section{Waste}

Landfills are also known to generate methane, which is not only a major greenhouse gas, but also an asphyxiant and highly flammable and potentially hazardous if a landfills grow unchecked (Figure 4). Population growth and urbanization have a proportional relationship with the production of waste, which in turn leads to greater demand for dumping grounds that are far removed from urban environments. These locations thus became a significant source of methane production. 


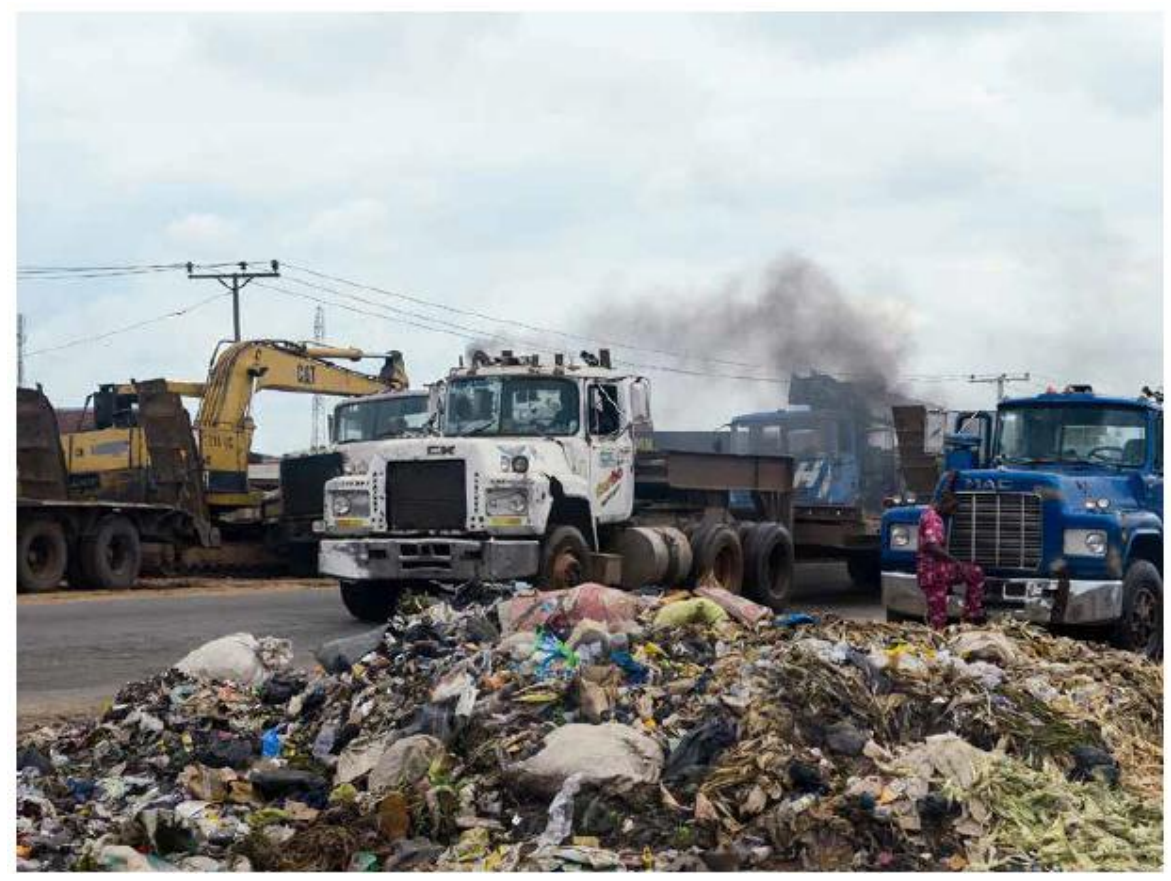

Figure 4: Waste disposal in a part of Lagos City, Nigeria (Adapted from Croitoru et al., 2019)

\section{EFFECTS OF AIR POLLUTION}

The effects of air pollution could be classified into two which are; health and environmental pollution.

\section{Health Effects}

Air pollution is a significant risk factor for a number of pollution-related diseases and health conditions including respiratory infections, heart disease, COPD, stroke and lung cancer according to WHO (2014). The health effects caused by air pollution may include difficulty in breathing, wheezing, coughing, asthma and worsening of existing respiratory and cardiac conditions. These effects can result in increased medication use, increased doctor or emergency room visits, more hospital admissions and premature death. The human health effects of poor air quality are far reaching, but principally affect the body's respiratory system and the cardiovascular system. Individual reactions to air pollutants depend on the type of pollutant a person is exposed to, the degree of exposure, and the individual's health status and genetics (Duflo et al., 2008). The most common sources of air pollution include particulates, ozone, nitrogen dioxide, and sulfur dioxide. Some examples include but not limited to the following;

\section{Lung disease}

Research has demonstrated increased risk of developing asthma (Provost et al., 2015) and COPD from increased exposure to traffic-related air pollution. Additionally, air pollution has been 
associated with increased hospitalization and mortality from asthma and COPD (Brook et al., 2010). Chronic obstructive pulmonary disease (COPD) includes diseases such as chronic bronchitis and emphysema (Louwies et al., 2013).

A study conducted in 1960-1961 in the wake of the Great Smog of 1952 compared 293 London residents with 477 residents of Gloucester, Peterborough, and Norwich, three towns with low reported death rates from chronic bronchitis. All subjects were male postal truck drivers aged 40 to 59 (Andersen et al., 2011). Compared to the subjects from the outlying towns, the London subjects exhibited more severe respiratory symptoms (including cough, phlegm, and dyspnea), reduced lung function $\left(\mathrm{FEV}_{1}\right.$ and peak flow rate), and increased sputum production and purulence (Andersen et al., 2011). The differences were more pronounced for subjects aged 50 to 59. Air pollution exposure also causes lung cancer in non smokers according to Andersen et al. (2011).

It is believed that much like cystic fibrosis, by living in a more urban environment serious health hazards become more apparent. Studies have shown that in urban areas patients suffer mucus hypersecretion, lower levels of lung function, and more self-diagnosis of chronic bronchitis and emphysema (Andersen et al., 2011).

\section{Cardiovascular disease}

A 2007 review of evidence found ambient air pollution exposure is a risk factor correlating with increased total mortality from cardiovascular events (range: $12 \%$ to $14 \%$ per $10 \mathrm{microg} / \mathrm{m}^{3}$ increase) (Törnqvist et al., 2007). Air pollution is also emerging as a risk factor for stroke, particularly in developing countries where pollutant levels are highest (Pope, 2003). A 2007 study found that in women, air pollution is not associated with hemorrhagic but with ischemic stroke (Chen et al. 2008). Air pollution was also found to be associated with increased incidence and mortality from coronary stroke in a cohort study in 2011 (Mateen \& Brook, 2011). Associations are believed to be causal and effects may be mediated by vasoconstriction, lowgrade inflammation and atherosclerosis (Miller et al., 2007).Other mechanisms such as autonomic nervous system imbalance have also been suggested (Andersen et al., 2011).

The following are listed air pollutants and the associated diseases (WHO, 2004; Nwachukwu et al., 2012):

i. Respiratory: Irritation and decreased pulmonary function.

ii. Particulate matter: Stress on the heart, bronchial constriction, impairment of lung elasticity and gaseous exchange efficient, silicosis (a form of pneumoconiosis caused by inhalation of dust particles), respiratory tract disease systematic toxicity, and altered immune defense.

iii. Cement dust: Pulmonary tuberculosis, allergic asthma, pneumonia, heart disease, bronchitis influenza emphysema, and mycosis.

iv. Carbon dioxide: Reduces the quantity of $\mathrm{O} 2$ transported to tissues, hence can impress extra burden on those suffering from anaemia, chronic lung conditions, heart and blood vessel diseases, brain damage, impaired perception, eye and nasal irritation, lung damage respiration tract disease. 
v. Lead/asbestos: Causes asbestosis (chronic lung cancer), and mesotheleliionia (a rare form of cancer). Kidney disease and neurological impairment, primarily affects children.

vi. Photochemical oxidants (e.g. ozone): Long exposure to it can cause reduced eye-sight, fatigue, pneumonia, pulmonary headache, breathing difficulties, chest pain, burning sensation to throat and eye, respiratory disease, aging of lungs and respiratory tissue.

vii. Sulfur dioxide: Respiratory irritation, shortness of breath, impaired pulmonary function, increased susceptibility to infection, illnesses to lower respiratory tracts (particularly in children), chronic lung disease, pulmonary fibrosis, increases toxicity in combination with other pollutants.

viii. Carbon monoxide: Interferes with oxygen uptake into the blood (chronic anoxia), heart and brain damage impaired perception, asphyxiation, weakness, headache and nausea.

ix. Nitrogen dioxide: Reduction in lung function, increase in mortality, increase in airway allergic inflammatory reaction, and increased probability of respiratory symptoms.

\section{Environmental Effects}

Along with harming human health, air pollution can cause a variety of environmental effects:

\section{Acid rain}

It is a precipitation containing harmful amounts of nitric and sulfuric acids (U.S. Environmental Protection Agency, 2020a). These acids are formed primarily by nitrogen oxides and sulfur oxides released into the atmosphere when fossil fuels are burned. These acids fall to the Earth either as wet precipitation (rain, snow, or fog) or dry precipitation (gas and particulates). Some are carried by the wind, sometimes hundreds of miles. In the environment, acid rain damages trees and causes soils and water bodies to acidify, making the water unsuitable for some fish and other wildlife (USEPA, 2020a). It also speeds the decay of buildings, statues, and sculptures that are part of our national heritage. Acid rain has damaged Massachusetts lakes, ponds, rivers, and soils, leading to damaged wildlife and forests (USEPA, 2020a).

\section{Eutrophication}

It is a condition in a water body where high concentrations of nutrients (such as nitrogen) stimulate blooms of algae, which in turn can cause fish kills and loss of plant and animal diversity. Although eutrophication is a natural process in the aging of lakes and some estuaries, human activities can greatly accelerate eutrophication by increasing the rate at which nutrients enter aquatic ecosystems. Air emissions of nitrogen oxides from power plants, cars, trucks, and other sources contribute to the amount of nitrogen entering aquatic ecosystems.

\section{Haze}

It is caused when sunlight encounters tiny pollution particles in the air. Haze obscures the clarity, color, texture, and form of what we see (USEPA, 2019). Some haze-causing pollutants (mostly fine particles) are directly emitted to the atmosphere by sources such as power plants, industrial facilities, trucks and automobiles, and construction activities. Others are formed when gases 
emitted to the air (such as sulfur dioxide and nitrogen oxides) form particles as they are carried downwind (USEPA, 2019).

\section{Effects on wildlife}

Toxic pollutants in the air, or deposited on soils or surface waters, can impact wildlife in a number of ways. Like humans, animals can experience health problems if they are exposed to sufficient concentrations of air toxics over time. Studies show that air toxics are contributing to birth defects, reproductive failure, and disease in animals. Persistent toxic air pollutants (those that break down slowly in the environment) are of particular concern in aquatic ecosystems. These pollutants accumulate in sediments and may biomagnify in tissues of animals at the top of the food chain to concentrations many times higher than in the water or air.

\section{Ozone depletion}

Ozone is a gas that occurs both at ground-level and in the Earth's upper atmosphere, known as the stratosphere. At ground level, ozone is a pollutant that can harm human health. In the stratosphere, however, ozone forms a layer that protects life on earth from the sun's harmful ultraviolet (UV) rays. But this "good" ozone is gradually being destroyed by man-made chemicals referred to as ozone-depleting substances, including chlorofluorocarbons, hydrochlorofluorocarbons, and halons. These substances were formerly used and sometimes still are used in coolants, foaming agents, fire extinguishers, solvents, pesticides, and aerosol propellants. Thinning of the protective ozone layer can cause increased amounts of UV radiation to reach the Earth, which can lead to more cases of skin cancer, cataracts, and impaired immune systems. UV can also damage sensitive crops, such as soybeans, and reduce crop yields.

\section{Crop and forest damage}

Air pollution can damage crops and trees in a variety of ways. Ground-level ozone can lead to reductions in agricultural crop and commercial forest yields, reduced growth and survivability of tree seedlings, and increased plant susceptibility to disease, pests and other environmental stresses (such as harsh weather). As described above, crop and forest damage can also result from acid rain and from increased UV radiation caused by ozone depletion.

\section{Global climate change}

The Earth's atmosphere contains a delicate balance of naturally occurring gases that trap some of the sun's heat near the Earth's surface (USEPA, 2020b). This "greenhouse effect" keeps the Earth's temperature stable. Unfortunately, evidence is mounting that humans have disturbed this natural balance by producing large amounts of some of these greenhouse gases, including carbon dioxide and methane. As a result, the Earth's atmosphere appears to be trapping more of the sun's heat, causing the Earth's average temperature to rise - a phenomenon known as global warming. Many scientists believe that global warming could have significant impacts on human health, agriculture, water resources, forests, wildlife, and coastal areas (USEPA, 2020b). 


\section{CASE HISTORY - THE NIGER DELTA REGION OF NIGERIA}

It has been difficult to achieve cooperation for air pollution control in developing countries like Nigeria, whose chief concern is to provide such basic need as food, shelter and employment for her populace (Tawari and Abowei, 2012).

Ever since the discovery of oil in Nigeria in the 1950's, the country has been suffering the negative environmental consequences of oil development (Tawari \& Abowei, 2012). The growth of the country's oil industry, combined with a population explosion and a lack of environmental regulation, led to substantial damage to Nigeria's environment especially in the Niger Delta region, the centre of the country's oil industry (Oyekunle, 1999; Tawari \& Abowei, 2012) see Figure 5 and 6.

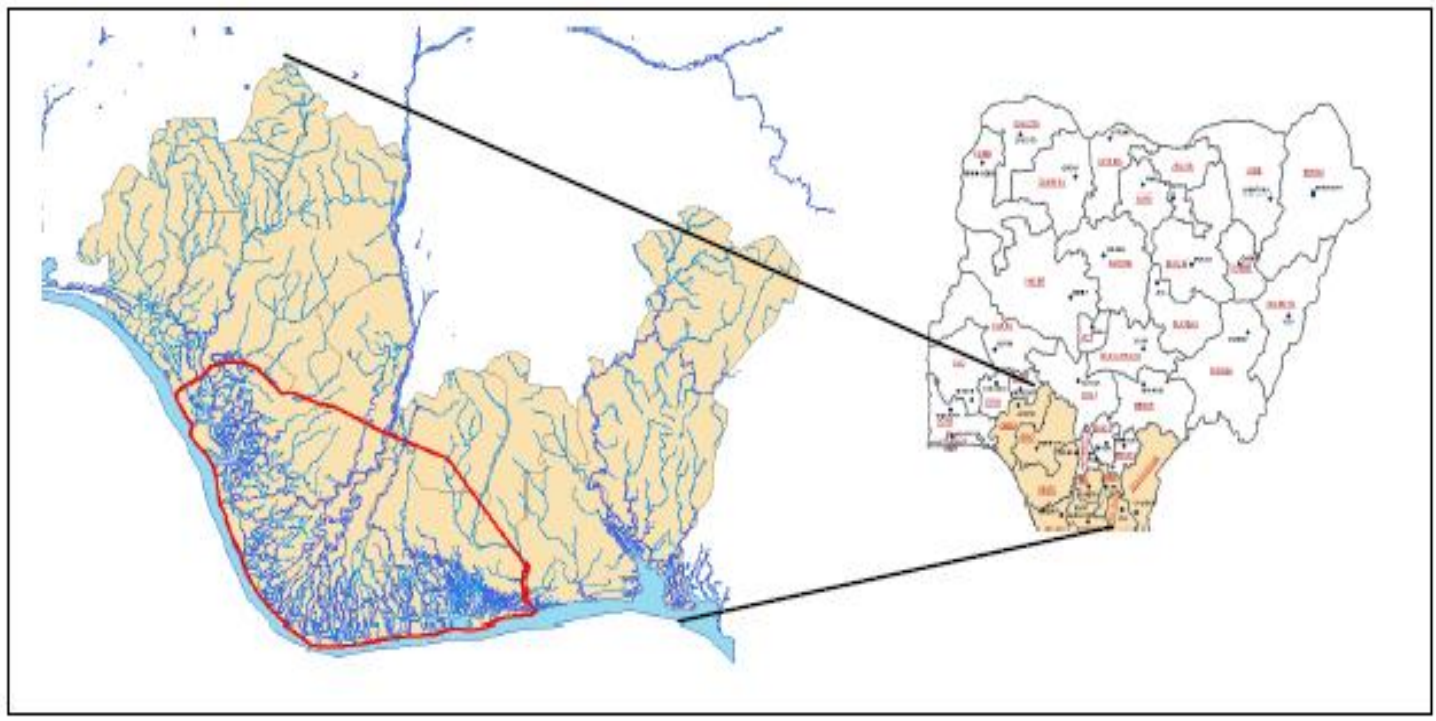

Figure 5: Map showing the approximate area defined as Niger Delta (Adapted Moffat \& Linden, 1995; United Nations Development Programme (UNDP) 2006; Fagbeja et al., 2008)

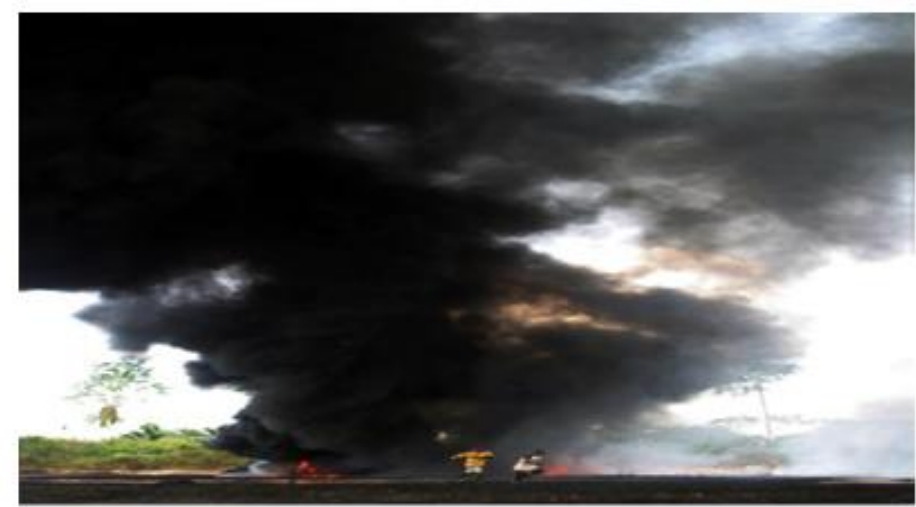

Figure 6: Niger delta air pollution (After Oyekunle, 1999; Tawari \& Abowei, 2012). 
The carelessness of the oil industry has also precipitated this situation, which can perhaps be best encapsulated by a 1983 report issued by the NNPC, long before popular unrest surfaced: The Niger Delta witnesses slow poisoning of the waters destruction of vegetation and agricultural land by air pollutants which occur during industrial operations. But since the inception of the oil industry in Nigeria, >25 years ago, there has been no concerned and effective effort on the part of the government, let alone the oil operators, to control environmental problems associated with the oil and gas industry' (Baird, 2010).

\section{Sources of air pollution in the Niger Delta}

Due to lack of infrastructure for providing clean energy to homes and poverty, majority of both the rural and urban populace in the Niger Delta depend on the use of fuel wood and kerosene for domestic cooking and lighting. This results in indoor air pollution and also contributes to ambient air pollution (Anozie et al., 2007; Fagbeja et al., 2008). Burning of fossil fuels for transportation in the inland urban and rural centres of the Niger Delta is another major source of air pollution in the region (Fagbeja et al., 2008). The majority of Nigerians cannot afford new vehicles due to prohibitive costs and, as a result, depend on vehicles which are older than the majority of cars used in Europe (Fagbeja et al., 2008).

Industrial emissions: Apart from Lagos which was the former political capital but still regarded as Nigeria's economic capital, the next most industrialized part of the country is the Niger Delta Area (Tawari \& Abowei, 2012) see Figure 7. The region boasts of oil and non oil related industries including refinery, petrochemical, liquefied natural gas, chemical fertilizer, aluminum smelter, paper, cement, flour, wood, battery and textile industries etc., which emit various kinds of air pollutants. The pollution from these industries adds to the burden of gaseous and particulate pollutants in the air. Tawari \& Abowei (2012) indicated that the major air pollutants in NDA gases are; $\mathrm{CO}_{2}, \mathrm{CH}_{4}, \mathrm{SO}_{2}, \mathrm{~N}_{2} \mathrm{O}, \mathrm{NO}_{2}, \mathrm{NH}_{3}$, VOCs and Particles: PM10, PM2.5, PAHs, Dioxins PAHs, Heavy metals.

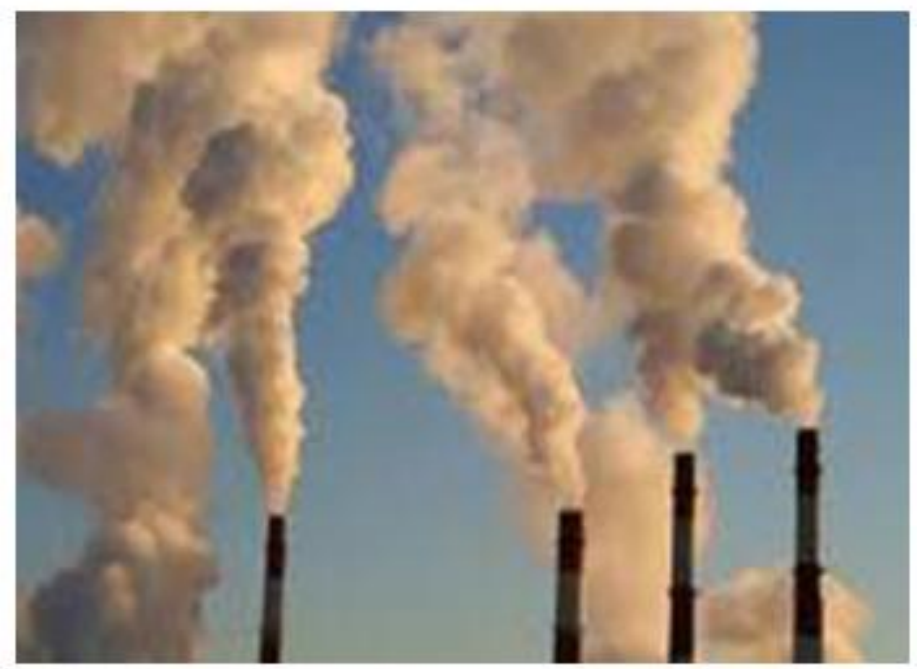

Figure 7: Cases of gas flare in the Niger delta (After Oyekunle, 1999; Tawari and Abowei, 2012). 
Gas flaring: According to Cedigaz, 2000, Nigeria holds the highest record (19.79\%) of natural gas flaring globally and is responsible for about $46 \%$ of Africa's total gas flared per tonne of oil produced. Until present there are not less than 123 flaring sites in the region making Nigeria one of the highest emitter of green house gases in Africa (Uyigue \& Agho, 2007). Much of the natural gas extracted in oil wells in the Niger Delta is immediately flared into the environment at a rate that approximates 70 million/m3/day. This is equivalent to $40 \%$ of African natural gas consumption and forms the single largest source of greenhouse gas emissions on the planet (Moffat \& Linden, 1995). Orubu (2002) who undertook a comparison of concentrations of ambient air pollutants in the region and Lagos State concludes that pollutant concentrations are highest in the Niger Delta and argues that some of the green house gases (such as methane and carbon dioxide) emitted at flare sites contribute to global warming. The largest proportion of these flare sites are located in the Niger Delta.

Gas flaring is generally discouraged as it releases toxic components into the atmosphere and contributes to climate change. Gas flares are often located close to local communities and regularly lack adequate fencing or protection for villagers who may risk working near heat of the flare. Many of these communities claim that nearby flares cause acid rain which corrodes their homes and other local structures, many of which have zinc-based roofing. Some people resort to the use of asbestos-based material, which is stronger in repelling acid rain deterioration (Bronwen, 1999).

Pipeline explosion: The explosion of pipelines occurs either accidentally or by sabotage (Figure 8). In the Niger Delta area much of the pipeline explosions are a product of the later and they are usually accompanied most times with fire outbreak as noted by Tawari and Abowei (2012). The burning flame and smoke from the oil pipelines releases large concentrations of gaseous substances and particulate matter. The substances in most cases include COx, NOx VOCs, THCs, carbon black, soot and some heavy metal residues (Tawari \& Abowei, 2012).

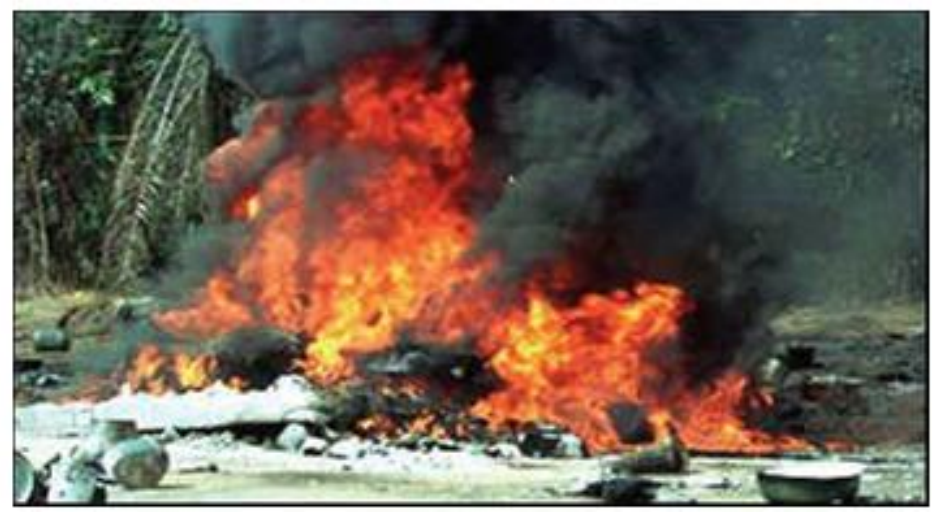

Figure 8: Emissions from fire outbreak following pipeline Explosion (After Oyekunle, 1999; Tawari \& Abowei, 2012) 
Journal DOI: 10.46654/ij.24889849

Table 1: Total air emissions from industry and households in Port Harcourt, Delta State and Calabar (Adapted from Ajao \& Anurigwo, 2002; Fagbeja et al., 2008).

\begin{tabular}{|c|c|c|c|}
\hline Location/Source & 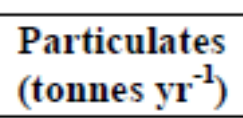 & $\begin{array}{l}\text { NOx } \\
\text { (tonnes } \mathrm{yr}^{-1} \text { ) }\end{array}$ & $\begin{array}{l}\text { NMVOC } \\
\left(\text { tonnes } \mathrm{yr}^{-1} \text { ) }\right.\end{array}$ \\
\hline $\begin{array}{l}\text { Port Harcourt } \\
\text { - Trans Amadi Industrial Area, including } \\
\text { NAFCON and refinery, exclusive of } \\
\text { solvents. } \\
\text { - Industries and households }\end{array}$ & $\begin{array}{l}10,496 \\
\text { Not available }\end{array}$ & $\begin{array}{l}779 \\
\text { Not available }\end{array}$ & $\begin{array}{l}292 \\
3,775\end{array}$ \\
\hline $\begin{array}{l}\text { Delta State } \\
\text { - Industries in Delta } \\
\text { - Solvents, small industries and households } \\
\text { in Warri }\end{array}$ & $\begin{array}{l}760.84 \\
1,535.5\end{array}$ & $\begin{array}{l}384.41 \\
\text { Not available }\end{array}$ & $\begin{array}{l}1,047.7 \\
\text { Not } \\
\text { available }\end{array}$ \\
\hline $\begin{array}{l}\text { Calabar } \\
\text { - Industries } \\
\text { - Solvents, small industries and households }\end{array}$ & $\begin{array}{l}35.43 \\
1,593.3\end{array}$ & $\begin{array}{l}20.83 \\
\text { Not available }\end{array}$ & $\begin{array}{l}29.93 \\
\text { Not } \\
\text { available }\end{array}$ \\
\hline
\end{tabular}

\section{CONTROL AND REMEDIATION}

\section{Control devices}

The following items are commonly used as pollution control devices by industry or transportation devices. They can either destroy contaminants or remove them from an exhaust stream before it is emitted into the atmosphere (Milton, 2005).

\section{Particulate control}

i. Mechanical collectors (dust cyclones, multicyclones)

ii. Electrostatic precipitators. An Electrostatic Precipitator (ESP) or electrostatic air cleaner is a particulate collection device that removes particles from a flowing gas (such as air) using the force of an induced electrostatic charge. Electrostatic precipitators are highly efficient filtration devices that minimally impede the flow of gases through the device and can easily remove fine particulate matter such as dust and smoke from the air stream.

iii. Bag houses designed to handle heavy dust loads, a dust collector consists of a blower, dust filter, a filter-cleaning system and a dust receptacle or dust removal system (distinguished from air cleaners which utilize disposable filters to remove the dust).

iv. Particulate scrubbers. Wet scrubber is a form of pollution control technology. The term describes a variety of devices that use pollutants from a furnace flue gas or from other gas streams. In a wet scrubber, the polluted gas stream is brought into contact with the 
scrubbing liquid, by spraying it with the liquid, by forcing it through a pool of liquid, or by some other contact method, so as to remove the pollutants.

v. Scrubbers: Baffle spray scrubber, Cyclonic spray scrubber, Ejector venturi scrubber, Mechanically aided scrubber, Spray tower, Wet scrubber

vi. NOx control: Low NOx burners, Selective Catalytic Reduction (SCR), Selective NonCatalytic, Reduction (SNCR) NOx scrubbers, Exhaust gas recirculation, Catalytic converter (also for VOC control).

vii. VOC abatement: Adsorption systems, such as activated carbon, Flares, Thermal oxidizers, Catalytic converters, Biofilters, Absorption (scrubbing), Cryogenic condensers, Vapor recovery systems.

viii. Acid Gas/SO2 control: Wet scrubbers, Dry scrubbers, Flue gas desulfurization.

ix. Mercury control: Sorbent Injection Technology, Electro-Catalytic Oxidation (ECO), KFuel Dioxin and furan control.

x. Miscellaneous associated equipment: Source capturing systems, Continuous Emissions Monitoring Systems (CEMS).

\section{CONCLUSION AND RECOMMENDATIONS}

There are now practical alternatives to the principal causes of air pollution. For instance, combustion of fossil fuels for space heating can be replaced by using ground source heat pumps and seasonal thermal energy storage (The Guardian, 2014). Electric power generation from burning fossil fuels can be replaced by power generation from nuclear and renewables. For poor nations, heating and home stoves that contribute much to regional air pollution can be replaced by a much cleaner fossil fuel like natural gas, or ideally, renewables.

Motor vehicles driven by fossil fuels, a key factor in urban air pollution can be replaced by electric vehicles. Though lithium supply and cost is a limitation, there are alternatives. Herding more people into clean public transit such as electric trains can also help. Nevertheless, even in emission-free electric vehicles, rubber tires produce significant amounts of air pollution themselves, ranking as 13th worst pollutant in Los Angeles (World Bank Group, 2016). Biodigesters can also be utilized in poor nations where slash and burn is prevalent, turning a useless commodity into a source of income. The plants can be gathered and sold to a central authority that will break it down in a large modern biodigester, producing much needed energy to use. According to Bell et al. (2004) induced humidity and ventilation both can greatly dampen air pollution in enclosed spaces, which was found to be relatively high inside subway lines due to braking and friction and relatively less ironically inside transit buses than lower sitting passenger automobiles or subways. Titanium dioxide has been researched for its ability to reduce air pollution. Ultraviolet light will release free electrons from material, thereby creating free radicals, which break up VOCs and NOx gases (NASA, 2018).

Finally, when it comes to the Niger Delta, there are numerous challenges facing air quality studies. Like in most developing nations the issues are intertwined and the most prominent have been lack of equipment, lack of infrastructure, inadequate expertise and weak policy frame work. This and many other factors have been the bane to achieving the much desired goals towards preserving the quality of the ecosystems and safeguarding the health of the public in the region and as a nation as well. 


\section{REFERENCES}

Air Pollution in the Megacities of Asia project (APMA) 2002. Benchmarking urban air quality management and practice in major and mega cities of Asia. Stage1. Prepared and published in the framework of the APMA Project by Haq G., Han W., Kim C., Vallack H., Korea Environment Institute, Seoul; pp. 6 - 108.

Ajao, E.A. and Anurigwo, S., 2002. Land-based sources of pollution in the Niger Delta, Nigeria. Ambio, 31: pp. 442-445.

Andersen, Z. J., Hvidberg, M., Jensen, S. S., Ketzel, M., Loft, S., Sorensen, M. and RaaschouNielsen, O., 2011. Chronic obstructive pulmonary disease and long-term exposure to traffic-related air pollution: a cohort study. [Research Support, Non-U.S. Gov't]. American Journal of Respiratory and Critical Care Medicine. 183 (4): pp.455-461. doi:10.1164/rccm.201006-0937OC.

Anozie, A.N., Bakare, A.R., Sonibare, A.J. and Oyebisi, T.O., 2007. Evaluation of cooking energy cost, efficiency, impact on air pollution and policy in Nigeria. Energy, 32: pp.1283-1290.

Bell, M. L., Devra L. D. and Fletcher, T., 2004. A Retrospective Assessment of Mortality from the London Smog Episode of 1952: The Role of Influenza and Pollution. Environ Health Perspect. 112 (1): pp.6-8. doi:10.1289/ehp.6539. PMC 1241789. PMID 14698923.

Baird, J., 2010. Oil's Shame in Africa. Newsweek, 27, July 26,

Brook, R. D., Rajagopalan, S., Pope, C. A III, Brook, J. R. and Bhatnagar, A., 2010. Particulate matter air pollution and cardiovascular disease: An update to the scientific statement from the American Heart Association. Circulation. 121: pp.2331-2378. doi:10.1161/cir.0b013e3181dbece1. PMID 20458016.

Bronwen, M., 1999. The Price of Oil Human Rights Watch. Perception and Reality: Assessing Priorities for Sustainable Development in the Niger River Delta

Chen, H., Goldberg, M. S. and Villeneuve, P.J., 2008. A systematic review of the relation between long-term exposure to ambient air pollution and chronic diseases. Reviews on environmental health. 23 (4): pp.243-97. doi:10.1515/reveh.2008.23.4.243. PMID 19235364.

Croitoru, L., Chang, J. C. and Kelly, A., 2019.The Cost of Air Pollution in Lagos. World Bank Group, pp.1-29

Duflo, E., Greenstone, M. and Hanna, R., 2008. Indoor air pollution, health and economic wellbeing. "S.A.P.I.EN.S." "'1'" (1)". Sapiens.revues.org.

Fagbeja, M. A., Chatterton, T. J., Longhurst, J. W. S., Akinyede, J. O. and Adegoke, J. O. 2008. Air pollution and management in the Niger Delta - emerging issues. WIT Transactions on Ecology and the Environment, Air Pollution XVI, 116: pp.207-216 
Fort Air Partnership (FAP) 2014. How is air quality monitored? Albrta Environment, Government of Alberta, www.fortair.org.

Grutter, M., Arellano, J., Bezanilla, H., Friedrich, M., Plaza, E., Rivera, C. and Stremme, W. 2014. Characterization of air pollution in Mexico city by remote sensing, Geophysical Research Abstracts pp.16, 1.

Louwies, T., Int Panis, L., Kicinski, M., De Boever, P. and Nawrot, T. S., 2013. Retinal Microvascular Responses to Short-Term Changes in Particulate Air Pollution in Healthy Adults. Environmental Health Perspectives. 121: pp.1011-6. doi:10.1289/ehp.1205721. PMC 3764070. PMID 23777785.

IPPC, 1996. Concerning integrated pollution prevention and control. Council Directive 96/61/EC of 24 September. Official Journal L 257, 10/10/1996 P. 0026 - 0040. 1996. Online: europa.eu/LexUriServ/LexUriServ.do?uri=CELEX:31996L0061:EN:H TML

Mateen, F. J., \& Brook, R. D., 2011. Air Pollution as an Emerging Global Risk Factor for Stroke. JAMA. 305 (12): pp.1240-1241. doi:10.1001/jama.2011.352. PMID 21427378.

Miller K. A., Siscovick D. S., Sheppard L., Shepherd K., Sullivan J. H., Anderson G. L. and Kaufman J. D., 2007. Long-term exposure to air pollution and incidence of cardiovascular events in women. The New England Journal of Medicine. Research Support, N.I.H., ExtramuralResearch Support, U.S. Gov't, Non-P.H.S. 356 (5): pp.447458. doi:10.1056/NEJMoa054409. PMID 17267905.

Milton, R.B., 2005. Fundamentals of Stack Gas Dispersion. 4th Edn., Flare Stack Plume Rise: 200, 1SBN: 0-9644588-0-2.

Molina, M. J., Ivanor, A.V., Trakhtenberg, S. and Molina, L.T., 2004. Atmospheric evolution of organic aerosol, Geophysical Research Letters 31, pp.1-5.

Moffat, D., \& Linden, O. (1995). Perception and reality: assessing priorities for sustainable development in the Niger River Delta. Ambio (Sweden).

NASA, 2018. NASA Confirms Biofuels Reduce Jet Emissions.

Njoku, P.C., \& Ibe, F. C., 2009. Heavy metal accumulation in electronic technicians in Owerri. J.Chem. Soc.Nigeria. 34(1), pp.1- 4.

Nwachukwu, A. N., Chukwuocha, E. O. and Igbudu, O., 2012. A survey on the effects of air pollution on diseases of the people of Rivers State, Nigeria. African Journal of Environmental Science and Technology, 6(10): pp.371-379, DOI: 10.5897/ AJEST12.024

Odigure, J.O., 1998. Safety Loss and Pollution Control in Chemical Process Industries. Jodigs and Associates, Minna, Nigeria, pp.89-93. 
Orubu, C.O., 2002. Oil Industry activities, Environmental Quality and the Paradox of Poverty in Niger Delta. In: The Petroleum Industry, the Economy and the Niger- Delta Environment. (Eds.), C.O. Orubu, D.O. Ogisi and R.N. Okoh: pp.17-31.

Oyekunle, L.O., 1999. Effect of gas flaring in Niger-Delta Area. NSChE Proceedings, PortHarcourt: p.13.

Pope, C. A., 2003. Cardiovascular Mortality and Long-Term Exposure to Particulate Air Pollution: Epidemiological Evidence of General Pathophysiological Pathways of Disease. Circulation. 109 (1), pp.71-77. doi:10.1161/01.CIR.0000108927.80044.7F. PMID 14676145.

Provost, E., Madhloum, N., Int Panis, L., De Boever, P. and Nawrot, T.S., 2015. Carotid intimamedia thickness, a marker of subclinical atherosclerosis, and particulate air pollution exposure: the meta-analytical evidence. PLoS ONE. 10 (5): e0127014. doi:10.1371/journal.pone.0127014. PMC 4430520 PMID 25970426.

Tawari, C.C. and Abowei, J.F.N., 2012. Air Pollution in the Niger Delta Area of Nigeria. International Journal of Fisheries and Aquatic Sciences 1(2): pp.94-117.

The Guardian, 2014. India air pollution 'cutting crop yields by almost half'.

Törnqvist, H. K.., Mills, N. L., Gonzalez, M., Miller, M. R., Robinson, S. D., Megson, I. L., MacNee, W., Donaldson, K., Söderberg, S., Newby, D. E., Sandström, T. and Blomberg, A., 2007. Persistent Endothelial Dysfunction in Humans after Diesel Exhaust Inhalation. American Journal of Respiratory and Critical Care Medicine. 176 (4): pp.395-400. doi:10.1164/rccm.200606-872OC. PMID 17446340.

United Nations Development Programme (UNDP) 2006. Niger delta human development report. UNDP, Abuja, Nigeria.

U.S. Environmental Protection Agency (EPA) 2019. Visibility and Regional Haze. http://www.epa.gov/oar/visibility/.

U.S. Environmental Protection Agency (EPA) 2020a. Effects of Acid Rain.

http://www.epa.gov/acidrain/

USEPA, 2020b. Understanding Global Warming Potentials

https://www.epa.gov/ghgemissions/understanding-global-warming-potentials

Uyigue, E. and Agho, M., 2007. Coping with Climate Change and Environmental Degradation in the Niger-Delta of South Nigeria. Community Research and Development Centre $(C R E D C)$, Benin.

WHO, 2004. Health aspects of air pollution. Results from WHO project "Systematic review of health aspects of air pollution in Europe". World Health Organization Regional Office for Europe. http//www.euro.who.int/document/E83080.pdf 
International Journal of Advanced Academic Research (Sciences, Technology and Engineering) | ISSN: 2488-9849

Journal DOI: 10.46654/ij.24889849

Vol. 7, Issue 1 (January, 2021) | www.ijaar.org

Article DOI: 10.46654/ij.24889849.e7114

WHO, 2014. 7 million premature deaths annually linked to air pollution. 25 March.

World Bank Group, 2016. The Cost of Air Pollution: Strengthening the Economic Case for Action. The World Bank and the Institute for Health Metrics and Evaluation at the University of

Washington, http://documents.worldbank.org/curated/en/781521473177013155/pdf/108141-

REVISED-Cost-of-PollutionWebCORRECTEDfile.pdf 